\title{
Kewenangan Notaris sebagai Pejabat Lelang Kelas II dalam Memberikan Penyuluhan Hukum atas Akta Risalah Lelang yang Dibuatnya
}

\author{
Muhammad Haris \\ Universitas Islam Negeri Antasari Banjarmasin \\ e-mail:mharis.mkn@gmail.com
}

\begin{abstract}
This study discusses the notary who has the authority to provide counseling or explanation of the contents of the auction minutes to the parties contained in the auction paper. The auction paper is the official documentation of the sale of the public in advance or the auction is arranged regularly and shall be accountable by the auction officer and the parties (the seller and the buyer) so that the implementation of the auction mentioned therein binds the parties. Notary Public as a Class II Auction Officer is also authorized to explain the function of the auction treaty that is as an authentic deed which has perfect evidentiary power. In addition, the Auction Report also serves as a basis for reversing the name / transfer/ transfer of rights in accordance with the objects listed in the auction paper.
\end{abstract}

Keywords: Auction, law, notary, deed, country.

Abstrak: Penelitian ini akan membahas mengenai tugas dan kewenangan notaris. Penelitian ini menemukan bahwa Notaris memiliki kewenangan untuk memberikan penyuluhan atau penjelasan tentang isi akta risalah lelang kepada para pihak yang ada di dalam risalah lelang tersebut. Risalah lelang adalah berita acara dokumen resmi dari jalannya penjualan dimuka umum atau lelang yang disusun secara teratur dan dipertanggung jawabkan oleh pejabat lelang dan para pihak (penjual dan pembeli) sehingga pelaksanaan lelang yang disebut didalamnya mengikat para pihak. Notaris selaku pejabat Lelang Kelas II juga berwenang menjelaskan fungsi dari risalah lelang yaitu sebagai akta otentik yang memiliki kekuatan pembuktian sempurna.

Kata kunci: Lelang, bukum, notaris, akta, negara.

\section{Latar Belakang Masalah}

Perkataan Notaris berasal dari perkataan Notarius, yakni nama pada zaman Romawi yang diberikan kepada orang-orang yang menjalankan pekerjaan menulis. Nama Notarius lambat laun mempunyai arti berbeda dengan semula, sehingga kira-kira pada abad kedua sesudah Masehi yang disebut dengan nama itu ialah mereka yang mengadakan pencatatan dengan tulisan cepat. ${ }^{1}$ Menurut sejarahnya, Notaris adalah seorang pejabat Negara dalam pelayanan hukum kepada masyarakat demi tercapainya kepastian hukum sebagai pejabat pembuat akta otentik dalam hal keperdataan. Notaris adalah suatu jabatan yang tidak digaji oleh pemerintah akan tetapi pegawai pemerintah yang berdiri seindiri dan mendapat honorarium dari orang-orang yang meminta jasanya.

1 R. Sugondo Notodisorjo, 2007, Hukum Notariat di Indonesia, PT. Raja Grafindo Persada, Jakarta, hlm. 13. 
Profesi notaris di Indonesia mempunyai sejarah yang cukup tua. Notaris sudah ada di Indonesia sejak abad ke - 17, atau lebih tepatnya sejak tanggal 27 Agustus 1620 Melchior Kerchem menjabat sebagai notaris pertama di Indonesia ${ }^{2}$. Profesi notaris sudah ada di Indonesia selama hampir empat abad. Pada masa itu notaris tidak memiliki kebebasan seperti sekarang karena merupakan pegawai dari Oost Indie ${ }^{3}$, berbeda dengan keadaan sekarang dimana notaris adalah seorang pejabat umum yang mandiri. Notaris merupakan suatu pekerjaan dengan keahlian khusus yang menuntut pengetahuan luas serta tanggung jawab yang berat untuk melayani kepentingan umum. Inti tugas notaris adalah mengatur secara tertulis dan otentik hubungan hukum antara para pihak yang secara mufakat meminta jasa notaris.

Secara administratif, notaris memiliki hubungan dengan negara dalam hal pemerintahan, misalnya yang berkaitan dengan pengangkatan dan pemberhentian notaris. Sedangkan menurut Komar Andasasmita, bentuk atau corak notaris dapat dibagi menjadi 2 (dua) kelompok utama yakni: ${ }^{4}$

Notariat functional, hal mana wewenang-wewenang pemerintah didelegasikan (gedelegeerd) dan demikian itu diduga mempunyai kebenaran isinya, mempunyai kekuatan bukti formal dan mempunyai daya/ kekuatan eksekusi. Di negara-negara yang menganut bentuk

\footnotetext{
2 GHS Lumban Tobing, 1983, Peraturan Jabatan Notaris, cet.III, Erlangga, Jakarta hlm 15.

${ }^{3}$ Ibid, hlm 17 .

${ }^{4}$ Komar Andasasmita, 1981, Notaris I, Sumur, Bandung, hlm 12.
}

notariat ini terdapat pemisahan yang keras antara wettelijke dan niet wetteljike, wekzaambeden yaitu pekerjaan-pekerjaan yang didasarkan undang-undang/hukum dan yang tidak/bukan dalam notariat.

Notariat profesional, dalam kelompok ini walaupun pemerintah mengatur tentang organisasinya tetapi akta-akta notaris ini tidak mempunyai akibat-akibat khusus tentang kebenarannya, kekuatan bukti demikian kekuatan eksekutorialnya.

Notaris diangkat oleh pemerintah bukan untuk kepentingan diri notaris sendiri melainkan untuk kepentingan masyarakat yang dilayaninya. Notaris sebagai pejabat umum, merupakan salah satu organ negara yang dilengkapi dengan kewenangan hukum untuk memberikan pelayanan umum kepada masyarakat, teristimewa dalam pembuatan Akta Otentik sebagai alat bukti yang sempurna berkenaan dengan perbuatan hukum di bidang keperdataan. ${ }^{5}$

Untuk membuat suatu Akta Otentik seorang Notaris harus mengikuti aturan- aturan yang telah diatur dalam undang-undang. Undang-Undang Nomor 30 Tahun 2004 tentang Jabatan Notaris dan Undang Undang Nomor 2 Tahun 2014 tentang perubahan atas UndangUndang Nomor 30 Tahun 2004 tentang Jabatan Notaris, yang merupakan dasar hukum Jabatan Notaris, sudah menentukan langkah demi langkah yang

5 N.G. Yudara, Notaris dan Permasalabannya Pokok-Pokok Pemikiran Di Seputar Kedudukan Dan Fungsi Notaris Serta Akta Notaris Menurut Sistem Hukum Indonesia), (Makalah disampaikan dalam rangka Kongres INI di Jakarta), Majalah Renvoi Nomor 10.34.III, Edisi 3 Maret 2006, Hlm. 72. Xiii 
harus dilakukan seorang Notaris apabila ia membuat suatu Akta Otentik. Langkahlangkah itu (antara lain mendengar pihak pihak mengutarakan kehendaknya, kemudian membacakan isi akta kepada para penghadap, menandatangani akta, dan lain-lain) memang khusus diadakan pembuat undang-undang untuk menjamin bahwa apa yang tertulis dalam akta itu memang mengandung apa yang dikehendaki para pihak. ${ }^{6}$

Perkembangan sosial yang cepat, mengakibatkan pula perkembangan hubungan-hubungan hukum di masyarakat, maka peranan Notaris menjadi sangat kompleks dan seringkali sangat berbeda dengan ketentuan yang berlaku. Dengan demikian kiranya sulit untuk mendefinisikan secara lengkap tugas dan pekerjaan Notaris. ${ }^{7}$ Walaupun demikian, seperti yang telah diuraikan, pada intinya tugas Notaris adalah mengatur secara tertulis dan otentik hubungan-hubungan hukum antara para pihak yang secara mufakat meminta jasa Notaris. Dari tugas utama Notaris tersebut, maka dapat dikatakan Notaris mempunyai tugas yang berat karena harus memberikan pelayanan kepada masyarakat dengan sebaik-baiknya. Notaris merupakan Jabatan tertentu yang menjalani profesi dalam pelayanan hukum kepada masyarakat, perlu mendapat perlindungan dan Jaminan demi tercapainya kepastian hukum. Jasa Notaris

6 Tan Thong Kie (b), Buku II Studi Notariat Serba Serbi Praktek Notaris, Cet. 1, (Jakarta : Ichtiar Baru Van Hoeve, 2000), Hlm. 261. xiv

${ }^{7}$ Habib Adjie, Tebaran Pemikiran Dalam Dunia Notaris Dan PPAT "Penegakan Etika Profesi Notaris Dari Prespektif Pendekatan Sistem", (Surabaya : Lembaga Kajian Notaris dan PPAT Indonesia, 2003), Hlm. 27 dalam proses pembangunan makin meningkat sebagai salah satu kebutuhan hukum masyarakat.

Dalam Pasal 1 angka 1 Undang Undang Jabatan Notaris menyebutkan bahwa Notaris adalah pejabat umum yang berwenang untuk membuat akta autentik dan memiliki kewenangan lainnya sebagaimana dimaksud dalam UndangUndang ini atau berdasarkan undangundang lainnya. Beberapa kewenangan lain tersebut diantaranya kewenagan berdasarkan Vendu Reglement dan vendu Instructie bahwa notaris dapat diangkat sebagai pejabat lelang kelas 2. Lahirnya UUJN juga melahirkan perkembangan hukum baru dalam dunia kenotariatan, salah satunya adalah perluasan kewenangan Notaris. Perluasan kewenangan tersebut dapat dilihat dari ketentuan Pasal 15 Ayat (2) butir f dan g, yang menyebutkan bahwa membuat akta yang berkaitan dengan pertanahan dan akta risalah lelang adalah merupakan salah satu wewenang Notaris.

Berdasarkan ketentuan Pasal 15 ayat (2) huruf e notaris memiliki kewenangan memberikan penyuluhan hukum sehubungan dengan pembuatan Akta. Salah satu akta tersebut yaitu risalah lelang. Notaris yang telah diangkat dan memiliki kewenangan lain sebagai pejabat lelang kelas II, berwenang membuat akta risalah lelang. Notaris sebagai Pejabat Lelang Kelas II berwenang melaksanakan lelang Noneksekusi Sukarela atas permohonan Balai Lelang atau Penjual/Pemilik Barang.

Konsep pelelangan yang merupakan bagian dari bidang ekonomi dan keuangan sangat digemari oleh masyarakat, terutama sejak berlakunya 
Venduu Reglement yang mengatur ketentuan tentang lelang, hal tersebut dikarenakan lelang berbeda dari jual beli biasa, dalam pelelangan barang yang dijual lebih banyak dan variatif, sehingga pembeli leluasa untuk memilih barang. Selain itu, kelebihan dari suatu sistim pelelangan adalah bahwa pembeli lelang seringkali mendapatkan harga lebih murah dari harga pasaran pada umumnya dan penjual akan lebih cepat mendapatkan pembeli barang yang akan di lelang.

Pengetahuan masyarakat mengenai pelelangan harus terus di sosialisasikan (melalui penyuluhan hukum) agar masyarakat dapat mengetahui secara lebih spesifik hal-hal yang berkaitan dengan pelelangan, baik peranan dan fungsinya maupun kelebihan-kelebihannya, sehingga dengan memasyarakatnya konsep pelelangan diharapkan dapat menjadi salah satu sarana untuk dapat menunjang roda perekonomian Indonesia. Pelelangan itu sendiri dapat dilakukan ditempat-tempat yang sudah ditentukan oleh undangundang, yaitu di Kantor Pelayanan Piutang dan Lelang Negara (KP2LN), di kantor Pejabat Lelang Kelas II atau Balai Lelang.

Adapun rumusan masalah ini adalah bagaimana Kewenangan Notaris sebagai Pejabat Lelang Kelas II dalam Memberikan Penyuluhan Hukum atas akta risalah lelang yang dibuatnya?

\section{Tinjauan umum tentang Notaris.}

Menurut definisi yang terdapat dalam Pasal 1 huruf 1 Undang-Undang No. 2 Tahun 20014 tentang Perubahan atas Undang-Undang No. 30 Tahun 2004 tentang Jabatan Notaris yaitu :
"Notaris adalah pejabat umum yang berwenang untuk membuat akta autentik dan memiliki kewenangan lainnya sebagaimana dimaksud dalam Undang-Undang ini atau berdasarkan undang-undang lainnya."

Kewenangan lain yang dimaksud dalam Undang-Undang yang berkaitan dengan akta otentik, yaitu terdapat pada Pasal 15 ayat (1) Undang-Undang Jabatan Notaris, yang menyatakan :

"Notaris berwenang membuat Akta autentik mengenai semua perbuatan, perjanjian, dan penetapan yang diharuskan oleh peraturan perundangundangan dan/atau yang dikehendaki oleh yang berkepentingan untuk dinyatakan dalam Akta autentik, menjamin kepastian tanggal pembuatan Akta, menyimpan Akta, memberikan grosse, salinan dan kutipan Akta, semuanya itu sepanjang pembuatan Akta itu tidak juga ditugaskan atau dikecualikan kepada pejabat lain atau orang lain yang ditetapkan oleh undangundang."

Pasal 15 ayat (2) menyebutkan Selain kewenangan sebagaimana dimaksud pada ayat (1), Notaris berwenang pula:

a. Mengesahkan tanda tangan dan menetapkan kepastian tanggal surat di bawah tangan dengan mendaftar dalam buku khusus;

b. Membukukan surat di bawah tangan dengan mendaftar dalam buku khusus;

c. Membuat kopi dari asli surat di bawah tangan berupa salinan yang memuat uraian sebagaimana ditulis dan digambarkan dalam surat yang bersangkutan; 
d. Melakukan pengesahan kecocokan fotokopi dengan surat aslinya;

e. Memberikan penyuluhan hukum sehubungan dengan pembuatan akta;

f. Membuat akta yang berkaitan dengan pertanahan; atau

g. Membuat Akta risalah lelang.

Para sarjana hukum memberikan pengertian mengenai notaris menurut pendapat Tan Thong Kie yaitu :

"Notaris adalah seorang fungsionaris dalam masyarakat, hingga sekarang jabatan seorang notaris masih disegani. Seorang notaris biasanya dianggap sebagai seorang pejabat tempat seseorang dapat memperoleh nasihat yang boleh diandalkan. Segala sesuatu yang ditulis serta ditetapkan (konstatir) adalah benar, ia adalah pembuatan dokumen yang kuat dalam suatu proses hukum". 8

Menurut Gandasubrata, notaris adalah pejabat umum yang diangkat oleh pemerintah termasuk unsur penegak hukum yang memberikan pelayanan kepada masyarakat. Di dalam tugasnya sehari-hari ia menetapkan hukum dalam aktanya sebagai otentik dan merupakan alat bukti yang kuat sehingga memberikan pembuktian yang lengkap kepada para pihak pembuatnya. $30^{9}$

Menurut R. Soegondo, notaris adalah pejabat umum, khususnya (satu-satunya) yang berwenang untuk membuat akta-akta

8 Tan Thong Kie, 2000, Buku I Studi Notariat Serba Serbi Praktek Notaris, Cet. 2, Ichtiar Baru Van Hoeve, Jakarta, hlm. 157

${ }^{9}$ H. R. Purwoto S. Gandasubrata, 1998, Renungan Hukum. IKAHI Cabang Mabkamah Agung RI, hlm. 484. otentik tentang semua tindakan, perjanjian-perjanjian, dan keputusankeputusan yang diharuskan oleh perundang-undangan umum untuk dikehendaki oleh yang berkepentingan bahwa hal itu dinyatakan dalam surat otentik, menjamin tanggalnya, menyimpan akta-akta dan mengeluarkan grosse, salinan-salinan (turunan-turunan) dan kutipankutipannya, semuanya itu apabila pembuatan akta-akta demikian itu atau dikhususkan itu atau dikhususkan kepada pejabat-pejabat atau orang-orang lain. ${ }^{10}$

\section{Peran Notaris Dalam Masyarakat}

Tugas dan wewenang Notaris erat hubungannya dengan perjanjian-perjanjian, perbuatan-perbuatan dan juga ketetapanketetapan yang menimbulkan hak dan kewajiban antara para pihak, yaitu memberikan jaminan atau alat bukti terhadap perbuatan, perjanjian, dan juga ketetapan tersebut agar para pihak yang terlibat di dalamnya mempunyai kepastian hukum. Jabatan Notaris diadakan atau kehadirannya dikehendaki oleh aturan hukum dengan maksud untuk membantu dan melayani masyarakat yang membutuhkan alat bukti tertulis yang bersifat otentik mengenai keadaan, peristiwa atau perbuatan hukum. ${ }^{11}$ Dengan dasar seperti ini mereka yang diangkat sebagai Notaris harus mempunyai semangat untuk melayani masyarakat. Dengan demikian, Notaris merupakan

10 R. Soegondo, 1982, Hukum Notariat di Indonesia suatu Penjelasa, Rajawali Pers, Jakarta, hlm 41.

11 Habib Adjie, Sanksi Perdata dan Administritif Terhadap Notaris Sebagai Pejabat Publik, (Bandung:

PT. Refika Aditama), 2008, Hlm. 32. 
suatu Jabatan Publik yang mempunyai kewenangan tertentu.

Kedudukan seorang Notaris sebagai suatu fungsionaris dalam masyarakat dianggap sebagai seorang pejabat tempat seseorang dapat memperoleh nasihat yang boleh diandalkan. Segala sesuatu yang ditulis serta ditetapkannnya (konstatir) adalah benar, ia adalah pembuat dokumen yang kuat dalam suatu proses hukum. ${ }^{12}$

\section{Penyuluhan Hukum}

Penyuluhan hukum merupakan bagian dari pembangunan hukum nasional, sedangkan pembangunan hukum nasional bagian dari pembangunan nasional. Kegiatan penyuluhan hukum merupakan salah satu sosialisasi untuk menggambarkan bagaimana itu keadilan. Hukum nasional tidak bisa penjamin terwujudnya keadilan itu. ${ }^{13}$

Adapun fungsi dari penyuluhan hukum adalah langkah pencegahan, langkah korektif, langkah pemeliharaan dan fungsi pengembangan. Pertama, penyuluhan sebagai langkah pencegahan (preventif), yakni mencegah timbulnya hak-hak yang negatif dan desdruktif yang dapat mengakibatkan kerugian bagi masyarakat. Kedua, penyuluhan sebagai langkah korektif, yakni berfungsi sebagai koreksi terhadap hal- hal yang telah ada, sehingga apabila terdapat suatu hal yang

12 Tan Thong Kie (a), Buku I Studi Notariat Serba Serbi Praktek Notaris, Cet. 2, (Jakarta : Ichtiar Baru

Van Hoeve, 2000), Hlm. 157.

13 Sudjito, Criical Legal Stidies (CLS) dan Hukum Progresif Sebagai Alternatif Dalam Reformasi Hukum Nasional dan Perubahan Kurikulum Pendidikan Hukum, Jurnal Ultimatum Sekolah Tinggi Ilmu Hukum Iblam, Vol. 2, Edisi September 2008, hlm. 3 melanggar hukum dapat mengurangi dampak ataupun menghilangkan hal tersebut. Ketiga, penyuluhan sebagai langkah pemeliharaan (presevatif), yakni memberikan dorongan untuk menumbuhkan semangat supaya berpartisipasi dalam pembangunan hukum sesuai dengan kemampuan dan kedudukannya masingmasing. Keempat, penyuluhan sebagai fungsi pengembangan (developmental), yakni memberikan dorongan dan masukan terhadap suatu hal agar masyarakat dapat lebih mandiri dan tidak tergantung ataupun mengandalkan pihak lain.

\section{Ketentuan Umum tentang Lelang}

Pasal 1 Vendu Reglement menyatakan:

"Penjualan di muka umum ialah pelelangan dan penjualan barang, yang diadakan di muka umum dengan penawaran harga yang makin meningkat, dengan persetujuan harga yang makin menurun atau dengan pendaftaran harga, atau di mana orangorang yang diundang atau sebelumnya sudah diberi tahu tentang pelelangan ataupenjualan, atau kesempatan yang diberikan kepada orang-orang yang berlelang atau membeli untuk menawar harga, menyetujui harga atau mendaftarkan"

\begin{tabular}{llrr}
\multicolumn{1}{c}{ Menurut } & PMK & No. 27/ \\
PMK.06/2016 & tentang & & Petunjuk \\
Pelaksanaan Lelang & & &
\end{tabular}

" Lelang adalah penjualan barang yang terbuka untuk umum dengan penawaran harga secara tertulis dan/atau lisan yang semakin meningkat atau menurun untuk mencapai harga tertinggi, yang didahului dengan pengumuman Lelang". 
Jenis lelang di Indonesia terbagi menjadi 3 macam, yaitu lelang eksekusi , lelang non eksekusi wajib dan lelang non eksekusi sukarela. Lelang yang sifatnya wajib adalah lelang yang dilaksanakan atas permintaan pihak yang menguasai/ memiliki suatu barang yang berdasarkan peraturan perundang-undangan harus dijual secara lelang. Lelang non eksekusi sukarela adalah lelang untuk melaksanakan penjualan barang milik perorangan, kelompok masyarakat atau badan swasta yang dilelang secara sukarela oleh pemiliknya, termasuk BUMN/D berbentuk persero. Lelang non sukarela dilaksanakan atas permintaan masyarakat/ pengusaha yang secara sukarela menginginkan barangnya di lelang.

Menurut Peraturan Menteri Keuangan Nomor 93/PMK.06/2010 tentang petunjuk pelaksanaan lelang, Pasal 7 menyebutkan:

$$
\text { "lelang noneksekusi sukarela }
$$
termasuk tetapi tidak terbatas pada : lelang barang milik BUMN/D berbentuk persero, Lelang harta milik bank dalam liquidasi kecuali ditentukan lain oleh peraturan perundang-undangan, lelang barang milik perwakilan Negara asing dan lelang barang milik swasta."

Pasal 8 Peraturan Menteri Keuangan Nomor 93/PMK.06/2010 tentang petunjuk pelaksanaan lelang, menyebutkan

(1) Pejabat lelang terdiri :

a. Pejabat lelang kelas I

b. Pejabat lelang kelas II

(2) Pejabat lelang kelas I berwenang melaksanakan lelang untuk semua jenis lelang atas permohonan Penjual/ Pemilik Barang

(3) Pejabat Lelang Kelas II berwenang melaksanakan lelang Noneksekusi Sukarela atas permohonan Balai Lelang atau Penjual/Pemilik Barang,

Pejabat lelang kelas II adalah orang yang khusus diberi wewenang oleh Menteri keuangan untuk melaksakan penjualan barang secara lelang atas permohonan Balai lelang selaku kuasa dari pemilik barang yang berkedudukan di Kantor pejabat lelang kelas II. Mereka berhak mendapat honorarium dan uang perurugi dari lelang yang dilaksanakan. Besaran honorarium Pejabat Lelang Kelas II adalah kesepakatan perdata antara pejabat Lelang Kelas II dengan balai Lelang dan menjadi beban balai lelang.

Risalah lelang adalah berita acara pelaksanaan lelang yang dibuat oleh pejabat lelang yang merupakan akta otentik dan mempunyai kekuatan pembuktian sempurna.

Kewenangan Notaris sebagai Pejabat Lelang Kelas II dalam Memberikan Penyuluhan Hukum atas akta risalah lelang yang dibuatnya.

Setelah proses lelang selesai dilaksanakan, notaris selaku Pejabat Lelang Kelas II akan mengeluarkan akta risalah lelang. Notaris memiliki kewenangan untuk memberikan penyuluhan atau penjelasan tentang isi akta risalah lelang kepada para pihak yang ada di dalam risalah lelang tersebut. Risalah lelang adalah berita acara dokumen resmi 
dari jalannya penjualan dimuka umum atau lelang yang disusun secara teratur dan dipertanggung jawabkan oleh pejabat lelang dan para pihak (penjual dan pembeli) sehingga pelaksanaan lelang yang disebut didalamnya mengikat. Penjelasan tersebut mengacu pada ketentuan Vendu Reglement (VR) Pasal 35 yang menyebutkan : Dari tiap-tiap penjualan umum yang dilakukan oleh juru lelang atau kuasanya, selama penjualan, untuk tiaptiap hari pelelangan atau penjualan harus dibuat berita acara tersendiri.

Melihat ketentuan tersebut istilah risalah lelang adalah istilah yang dipakai oleh para akademisi maupun praktisi hukum untuk menyebut berita acara yang dimaksud dalam Pasal 35 VR tersebut. pada perkembangannya istilah tersebut memperoleh legitimasi yakni dalam Peraturan Menteri Keuangan Nomor 106/PMK.06/2013 tentang Petunjuk Pelaksanaan Lelang Pasal 1 angka 32 yang menyebutkan bahwa :Risalah Lelang adalah berita acara pelaksanaan lelang yang dibuat oleh Pejabat Lelang yang merupakan akta otentik dan mempunyai kekuatan pembuktian sempurna. Legitimasi tersebut mempertegas penyebutan berita acara pelaksanaan lelang sebagai Risalah Lelang. Pada Pasal tersebut dinyatakan bahwa Risalah Lelang adalah merupakan akta otentik dan mempunyai kekuatan pembuktian sempurna bagi para pihak. Hal itu berarti isi pasal tersebut terkait dengan apa yang dimaksud dengan akta otentik itu, yang oleh peraturan perundang-undangan telah dijelaskan dalam Pasal 165 HIR, 285 Rbg, dan 1868BW. Untuk hal ini ketentuan 1868 BW yang lebih mendekati dengan permasalahan yakni :Suatu akta otentik adalah suatu akta yang dalam bentuk yang ditentukan oleh undang-undang dibuat oleh atau dihadapan pejabat umum yang berkuasa untuk itu ditempat dimana akta itu dibuat.

Perluasan kewenangan kepada Notaris untuk membuat akta risalah lelang yangdisebutkan dalam Pasal 15 Ayat 2 huruf $g$ Undang-undang Jabatan Notaris tidak secara serta merta dapat dlaksanakan karena berdasarkan Pasal 35 Vendu Reglement Jo. Peraturan Menteri Keuangan Nomor 175/PMK.06/2010 hanya notaris yang telah ditetapkan dan diangkat menjadi Pejabat Lelang Kelas II saja yang berwenang meminpin pelaksanaan lelang dan membuat akta risalah lelang

Risalah Lelang merupakan Legal Output dari Pejabat Lelang kelas II. Menurut pasal 1868 Jo Pasal 37,38 dan 39 VR, Risalah Lelang termasuk akta otentik. Selanjutnya menurut pasal 1870 akta otentik merupakan bukti yang sempurna. Risalah lelang juga merupakan salah satu bentuk perjanjian yang dibuat secara sah berlaku sebagai undang-undang bagi para pihak, " Persetujuan-persetujuan itu tidak dapat ditarik kembali selain dengan sepakat kedua belah pihak dan persetujuan harus dilaksanakan dengan itikad baik"

Pasal 35 VR mengatur Risalah Lelang sama artinya dengan "Berita Acara" Lelang. Berita Acara Lelang merupakan landasan otentifikasi penjualan lelang, berita acara lelang mencatat segala peristiwa yang terjadi pada penjualan lelang. Menurut pasal 35 VR mengatakan “ Tiap penjualan di muka umum oleh juru 
lelang atau kuasanya dibuat berita acara tersendiri yang bentuknya ditetapkan seperti dimaksud dalam pasal 37, 38 dan 39 VR"

Dalam perkembangannya istilah berita acara lelang tersebut berubah menjadi risalah lelang. Sejak kapan penggunaan risalah lelang tersebut resmi belum diketahui akan tetapi istilah risalah lelang itu menurut Pedoman Administrasi Umum Departemen Keuangan dapat diartikan sebagai berikut :

a. Berita acara adalah risalah mengenai suatu peristiwa remsi dan kedinasan yang disusun secara teratur dimaksudkan untuk mempunyai kekuatan bukti tertulis bilamana diperlukan sewaktu-waktu. Berita acara ini ditandatangani oleh pihakpihak yang bersangkutan.

b. Risalah adalah laporan mengenai jalannya suatu pertemuan yang disusun secara teratur dan dipertanggungjawabkan oleh si pembuat dan/atau pertemuan itu sendiri, sehingga mengikat sebagai dokumen resmi dari kejadian/peristiwa yang disebutkan didalamnya.

Dari kedua pengertian tentang berita acara dan risalah tersebut di atas, maka dapat disimpulkan bahwa risalah lelang adalah : “ Berita acara yang merupakan dokumen resmi dari jalannya penjualan dimuka umum atau lelang yang disusun secara teratur dan dipertanggungjawabkan oleh pejabat lelang dan para pihak (penjualan dan pembelian sehingga pelaksanaan lelang yang disebut didalamnya mengikat". Pasal 37 VR yaang selanjutnya diatur dalam pasal 77 Permenkeu Nomor 93/PMK.06/2010, mengatur lebih teknis hal-hal yang harus tercantum dalam risalah lelang.:

(1)Pejabat Lelang yang melaksanakan lelang wajib membuat berita acara lelang yang disebut Risalah Lelang.

(2) Risalah Lelang terdiri dari:

a Bagian Kepala;

b. Bagian Badan; dan

c. Bagian Kaki.

(3) Risalah Lelang dibuat dalam Bahasa Indonesia.

(4) Setiap Risalah Lelang diberi nomor urut.

Pasal 78 menyebutkan bahwa :

Bagian Kepala Risalah Lelang paling kurang memuat:

a. Hari, tanggal, dan jam lelang ditulis dengan huruf dan angka;

b. Nama lengkap dan tempat kedudukan pejabat lelang;

c. Nomor/tanggal surat keputusan pengangkatan pejabat lelang, dan nomor/tanggal surat tugas khusus untuk pejabat lelang kelas i;

d. Nama lengkap, pekerjaan dan tempat kedudukan/domisili penjual;

e. Nomor/tanggal surat permohonan lelang;

f. Tempat pelaksanaan lelang;

g. Sifat barang yang dilelang dan alasan barang tersebut dilelang;

h. Dalam hal yang dilelang berupa barang tidak bergerak berupa tanah 
atau tanah dan bangunan harus disebutkan:

1) Status hak atau surat-surat lain yang menjelaskan bukti kepemilikan;

2) Skt dari kantor pertanahan; dan

3)Keterangan lain yang membebani, apabila ada;

i. Dalam hal yang dilelang barang bergerak harus disebutkan jumlah, jenis dan spesifikasi barang;

j. Cara pengumuman lelang yang telah dilaksanakan oleh penjual;

k. Cara penawaran lelang; dan

1. Syarat-syarat lelang.

a. Bagian Kepala.

b. Bagian Badan dan

c. Bagian Kaki

Selanjutnya bagian kepala risalah lelang memuat sekurang-kurangnya :

a. Hari, tanggal, dan jam lelang ditulis dengan huruf dan angka

b. nama lengkap, pekerjaan dan tempat tinggal/domisili dari pejabat lelang.c. Nama lengkap, pekerjaan dan tempat tinggal/ domisili penjual.

d. Nomor/tanggal surat permohonan lelang.

e. Tempat pelaksanaan lelang. f. Sifat barang yang dilelang dan alasan barang tersebut dilelang.

g. Dalam hal yang dilelang barangbarang tidak bergerak berupa rumah atau tanah dan bangunan harus disebutkan:

1. status hak tanah atau suratsurat lain yang menjelaskan bukti kepemilikan.

2. Surat keterangan tanah dari kantor pertanahan, dan.

3. Keterangan lain yang membebani tanah tersebut.

h. Cara bagaimana lelang tersebut telah diumumkan oleh penjual, dan. i. Syarat-syarat umum lelang.

Bagian Badan risalah lelang memuat sekurang-kurangnya

a. Banyaknya penawaran lelang yang masuk dan sah.

b. Nama barang yang dilelang.

c. Nama pekerjaan dan alamat pembeli, sebagai pembeli atas nama sendiri atau sebagai kuasa atas nama orang lain.

d. Bank Kreditor sebagai pembeli untuk orang atau badan hukum atau badan usaha yang akan ditunjuk namanya (dalam hal bank kreditor sebagai pembeli lelang).

e. Harga lelang dengan angka dan huruf, dan.

f. Daftar barang yang laku terjual/ditahan memuat nilai, nama, alamat pembeli.

Bagian Kaki Risalah Lelang memuat sekurang-kurangnya : 
a. Banyaknya barang yang ditawarkan/dilelang dengan angka dan huruf.

b. Jumlah nilai barang-barang yang telah terjual dengan angka dan huruf.

c. Banyaknya surat-surat yang sudah dilampirkan pada risalah lelang dengan angka dan huruf. d. Jumlah nilai barang-barang yang ditahan dengan angka dan huruf.

e. Jumlah perubahan yang dilakukan (catatan, tambahan, coretan dengan penggantinya).

f.Tandatangan pejabat lelang, penjual/kuasa penjual dalam hal lelang barang tidak bergerak, atau.

g. Tandatangan pejabat lelang, penjual/kuasa penjual dan pembeli/kuasa pembeli lelang hal lelang barang tidak bergerak. Sebagai suatu akta, maka penandatanganan risalah lelang dilakukan oleh pejabat lelang, penjual/kuasa pembeli/kuasa pembeli dalam hal lelang barang tidak bergerak.

Apabila penjual tidak menghendaki menandatangani risalah lelang atau tidak hadir setelah risalah lelang ditutup, hal ini dinyatakan oleh pejabat lelang sebagai tanda tangan, pihak yang berkepentingan dapat memperoleh salinan/petikan/grosse yang otentik dari minut risalah lelang yaitu : pembeli, penjual, instansi pemerintah untuk kepentingan dinas, kantor lelang. Grosse risalah lelang yang berkepala “ Demi Keadilan Berdasarkan Ketuhanan Yang Maha Esa:, dapat diberikan atas permintaan pembeli atau kuasananya. Risalah Lelang sebagai perjanjian yang mengikat para pihak dalam lelang. Klausul risalah lelang yang merupakan hukum khusus yang berlaku bagi para pihak dalam lelang yang berfungsi sebagai perjanjian baku, perjanjian baku atau standar kontrak merupakan perjanjian yang telah ditentukan dan telah dituangkan dalam bentuk formulir. ${ }^{14}$ Notaris selaku pejabat lelang kelas II memiliki kewajiban yang sama untuk membacakan isi akta risalah lelang kepada para pihak yang terkait dalam akta risalah lelang.

Notaris sebagai Pejabat Lelang Kelas II harus juga menjelaskan fungsi dari akta risalah lelang yang dibuatnya kepada para pihak. Risalah Lelang berfungsi sebagai Akta Otentik dan mempunyai kekuatan pembuktian yang sempurna.

Risalah lelang sebagai akta otentik juga dapat digunakan sebagai alat bukti/tercatat dari suatu peristiwa penting yang mempunyai akibat hukum. Suatu peristiwa penting yang mempunyai akibat hukum, misalnya suatu transaksi atau suatu perikatan, perlu adanya pembuktian sebagai bukti bisa digunakan kesaksian dari yang melihat peristiwa itu, akan tetapi saksi hidup ini mempunyai kelemahankelemahan yaitu bila suatu peristiwa akan dibuktikan kebenarannya, saksi-saksi itu sudah tidak ada lagi. Oleh karena adanya kelemahan untuk pembuktian dengan saksi hiduptersebut, pihak-pihak yang berkepentingan mulai mencari dan menyadari pentingnya bukti-bukti tertulis. Mereka mulai mencatat dalam suatu surat (dokumen) dan ditandatangani oleh pihak

14 Purnama Tioria Sianturi, 2013, Perlindungan Hukum Terbadap Pembeli Barang Jaminan Tidak. Bergerak melalui Lelang, Mandar Maju, Bandung hlm 109 
yang berkepentingan berikut saksisaksinya.

Risalah Lelang juga berfungsi sebagai dasar untuk melakukan balik nama/ peralihan/pemindahan hak sesuai benda yang dicantumkan dalam risalah lelang tersebut kepada institusi yang berwenang. Masyarakat yang membeli barang / tanah/ bangunan melalui lelang akan lebih terjamin keabsahannya, dengan kata lain Pejabat Lelang sudah memastikan objek lelang itu tidak bermasalah.

Dengan diberikannya penjelasan tentang isi akta risalah lelang kepada para pihak lelang tersebut, akan memberikan dampak adanya rasa percaya dari para pihak yang melakukan lelang kepada notaris selaku pejabat lelang kelas II. Dengan tingginya rasa percaya dan aman kepada notaris tersebut diharapkan akan memicu peningkatan frekuensi lelang noneksekusi sukarela dari masyarakat.

\section{Kesimpulan}

Notaris memiliki kewenangan untuk memberikan penyuluhan atau penjelasan tentang isi akta risalah lelang kepada para pihak yang ada di dalam risalah lelang tersebut. Risalah lelang adalah berita acara dokumen resmi dari jalannya penjualan dimuka umum atau lelang yang disusun secara teratur dan dipertanggung jawabkan oleh pejabat lelang dan para pihak (penjual dan pembeli) sehingga pelaksanaan lelang yang disebut didalamnya mengikat para pihak. Notaris selaku pejabat Lelang Kelas II juga berwenang menjelaskan fungsi dari risalah lelang yaitu sebagai akta otentik yang memiliki kekuatan pembuktian sempurna.
Selain itu Risalah Lelang juga berfungsi sebagai dasar untuk melakukan balik nama/ peralihan/pemindahan hak sesuai benda yang dicantumkan dalam risalah lelang. Dengan diberikannya penjelasan tentang isi akta risalah lelang kepada para pihak lelang tersebut, akan memberikan dampak adanya rasa percaya dari para pihak yang melakukan lelang kepada notaris selaku pejabat lelang kelas II. Dengan tingginya rasa percaya dan aman kepada notaris tersebut diharapkan akan memicu peningkatan frekuensi lelang noneksekusi sukarela dari masyarakat

\section{Saran}

Notaris sebagai Pejabat Lelang Kelas II diharapkan harus terus aktif memberitahukan kepada masyarakat kelebihan lelang noneksekusi sukarela dan menjelaskan fungsi juga manfaat dari risalah lelang.

\section{Daftar Pustaka}

Adjie, Habib, Tebaran Pemikiran Dalam

Dunia Notaris Dan PPAT

"Penegakan Etika Profesi Notaris

Dari Prespektif Pendekatan

Sistem”, (Surabaya : Lembaga

Kajian Notaris dan PPAT Indonesia, 2003

, Sanksi Perdata dan Administritif Terhadap Notaris Sebagai Pejabat Publik, (Bandung: PT. Refika Aditama), 2008,

Andasasmita,Komar, 1981, Notaris I, Sumur, Bandung

Gandasubrata, H. R. Purwoto S. , 1998, Renungan Hukum. IKAHI Cabang Mabkamah Agung RI, 
Kie, Tan Thong 2000, Buku I Studi Notariat Serba Serbi Praktek Notaris, Cet. 2, Ichtiar Baru Van Hoeve, Jakarta

Notodisorjo, R. Sugondo, 2007, Hukum Notariat di Indonesia, PT. Raja Grafindo Persada, Jakarta

Sianturi, Purnama Tioria 2013, Perlindungan Hukum Terbadap Pembeli Barang Jaminan Tidak Bergerak melalui Lelang, Mandar Maju, Bandung

Soegondo,R 1982, Hukum Notariat di Indonesia suatu Penjelasa, Rajawali Pers, Jakarta

Sudjito, Critical Legal Stidies (CLS) dan Hukum Progresif Sebagai Alternatif Dalam Reformasi Hukum
Nasional dan Perubahan Kurikulum Pendidikan Hukum, Jurnal Ultimatum Sekolah Tinggi Ilmu Hukum Iblam, Vol. 2, Edisi September 2008

Tobing, GHS Lumban 1983, Peraturan Jabatan Notaris, cet.III, Erlangga, Jakarta

Yudara, N.G. Notaris dan Permasalahannya (Pokok-Pokok Pemikiran Di Seputar Kedudukan Dan Fungsi Notaris Serta Akta Notaris Menurut Sistem Hukum Indonesia), (Makalah disampaikan dalam rangka Kongres INI di Jakarta), Majalah Renvoi Nomor 10.34.III, Edisi 3 Maret 2006, Hlm. 72. Xii 